\title{
The involvement of p38 MAPK in transforming growth factor $\beta 1$-induced apoptosis in murine hepatocytes
}

\author{
LIAO Jin Hui, Jun Song CHEN, Min Qiang CHAI, Sheng ZHAO, Jian Guo SONG*
}

State Key Laboratory of Molecular Biology, Institute of Biochemistry and Cell Biology, Shanghai Institutes for Biological Sciences, Chinese Academy of Sciences, 320 Yue Yang Road, Shanghai 200031, China

\begin{abstract}
We reported in this manuscript that TGF- $\beta 1$ induces apoptosis in AML12 murine hepatocytes, which is associated with the activation of p38 MAPK signaling pathway. SB202190, a specific inhibitor of p38 MAPK, strongly inhibited the TGF- $\beta 1$-induced apoptosis and PAI-1 promoter activity. Treatment of cells with TGF$\beta 1$ activates $\mathrm{p} 38$. Furthermore, over-expression of dominant negative mutant $\mathrm{p} 38$ also reduced the TGF- $\beta 1$ induced apoptosis. The data indicate that the activation of $\mathrm{p} 38$ is involved in TGF- $\beta 1$-mediated gene expression and apoptosis.
\end{abstract}

Key words: Transforming growth factor $\beta$, apoptosis, p38, hepatocyte, signal transduction.

\section{INTRODUCT ION}

Apoptosis is a fundamental important biological process that is required to maintain the integrity and homeostasis of multicellular organism[1]. It seems that apoptosis is a predominant type of active cell death in the liver. Endogenous factors, such as transforming growth factor $\beta 1$ (TGF- $\beta 1$ ), activin A, CD95 ligand, and tumor necrosis factor (TNF) may be involved in induction of apoptosis in the liver[2].

Transforming growth factor $\beta$ (TGF- $\beta$ ) is a member of a super-family of multifunctional cytokines that regulate cell proliferation, differentiation, and apoptosis. Investigating the signaling pathways induced by TGF- $\beta$ is important for the understanding of the mechanism that underlies the various biological events mediated by TGF- $\beta$. It was demonstrated that increased PLD activity are involved in TGF- $\beta$-induced growth inhibition of several types of epithelial cell lines[3]. TGF- $\beta$ can induce apoptosis in normal hepatocytes[4-7] and hepatoma cells[8],[9]. It has been found that TGF- $\beta$-induced

*Corresponding author, Tel and Fax: (86)-21-6431-7660; Email: songj@sunm.shenc.ac.cn

Abbreviations: MAPK, mitogen-activated protein kinase; TGF$\mathrm{b}$, transforming growth factor $\mathrm{b}$; TAK1, TGF-b activated kinase 1 ; JNK, c-jun N-terminal kinase; ERK, extracellular signal-regulated kinase.

Received April-2-2001 Revised April-20-2001 Accepted April- apoptosis is associated with the generation of reactive oxygen species (ROS)[10],[11]. Anti-oxidants, such as vitamin $\mathrm{C}$, can block the TGF- $\beta$-induced apoptotic process[12]. Recently, several reports provide evidence showing that TGF- $\beta$-induced apoptosis can be mediated by caspases[5],[9], [13], [14]. It has also been reported that TGF- $\beta$ induces apoptosis through the regulation of the expression of pro- and anti-apoptotic molecules, such as p53, Bax, Bik, Bcl-2, and Bcl-X $\mathrm{X}_{\mathrm{L}}[6],[14],[15]$.

TGF- $\beta$ exerts its action through binding with type I and type II serine/threonine kinase receptors. The signaling events downstream of these receptor complexes are mediated by Smad family. Following phosphorylation by the type I receptor, Smad2 or Smad3 forms a heteromeric complex with Smad4. The complex formed then translocates to the nucleus where it can directly or indirectly regulate gene transcription[16-19]. In addition to the Smad pathway, another signaling pathway of TGF- $\beta$ involves the TGF- $\beta$ activated kinase 1 (TAK1), which was identified as a member of MAP kinase family[20]. It has been known that TAK1 kinase can acitvate p38 mitogen-activated protein kinase (p38 MAPK) and c-Jun Nterminal kinase (JNK) [21-23].

p38 and JNK are members of MAP kinase superfamily, which have been implicated in the re- 
sponses to stress and inflammation. Although p38 and JNK mediate a wide range of biological effects, the activations of p38 and JNK by some stimuli result in apoptosis[24-28]. However, the signaling mechanism of TGF- $\beta$-induced apoptosis remains poorly understood. Since p38 and JNK are often activated by TGF- $\beta$ and TGF- $\beta$-induced gene expression can be mediated by p38 and JNK [2123], [29],[30], it is likely that p38 and JNK are involved in TGF- $\beta$-induced apoptosis. To investigate this possibility, we studied the involvement of p38 and JNK signaling components in TGF- $\beta$-induced apoptosis in AML12 murine hepatocytes.

\section{MATERIALS AND METHODS}

\section{Materials}

Cell culture reagents and fetal bovine serum (FCS) were purchased from GIBCO. The polyclonal antibodies against p38 and JNK and the monoclonal antibodies against phosphorylated p38 MAPK and phosphorylated JNK were bought from Santa Cruz (USA). LipofectAMINE was purchased from GIBCO BRL (USA). Dual luciferase assay system was purchased from Promega (USA).

\section{Methods}

Cell culture

AML-12 murine heptocytes (American Tissue Culture Collection, ATCC CRL-2254) were cultured in a 1:1 mixture of Dulbecco's modified Eagle's medium and Ham's F12 medium containing insulin $(5 \mu \mathrm{g} / \mathrm{ml})$, transferrin $(5 \mu \mathrm{g} / \mathrm{ml})$, selenium (5 $\mu \mathrm{g} / \mathrm{ml}$ ), dexamethasone ( $40 \mathrm{ng} / \mathrm{ml}$ ), and $10 \%$ fetal bovine serum. Cell cultures were maintained at $37^{\circ} \mathrm{C}$ in a humidified atmosphere of $5 \% \mathrm{CO}_{2}$.

Assessment of apoptosis

Morphological evaluation was performed as described[31]. Briefly, medium was gently removed after treatment to prevent detachment of cells. Cells were stained by acridine orange $(2 \mu \mathrm{g} /$ $\mathrm{ml})$ and ethidium bromide $(2 \mu \mathrm{g} / \mathrm{ml})$ in PBS. Fluorescence was visualized immediately with a fluorescent microscope. The normal cells appear uniformly green. Early apoptotic cells can be stained green and contain bright green dots in the nuclei as a consequence of chromatin condensation and nuclear fragmentation. Late apoptotic cells will be incorporated by ethidium bromide and therefore stained orange with condensed and often fragmented nuclei.

DNA fragmentation of apoptotic cells was detected as described by Lindenboim et al[32] with minor modifications. The cells were rinsed with PBS twice and lysed on ice for $30 \mathrm{~min}$ in 10 $\mathrm{mM}$ Tris-Cl pH 8.0, 25 mM EDTA pH 8.0, and 0.25\% Triton X100. After centrifugation at $13,800 \times \mathrm{g}$ for $15 \mathrm{~min}$, the supernatant was incubated with RNase at $37^{\circ} \mathrm{C}$ for $60 \mathrm{~min}$ and then with proteinase $\mathrm{K}$ at $56^{\circ} \mathrm{C}$ overnight. The contents were extracted sequentially with phenol, phenol:chloroform(1:1) and chloroform. The DNAs in aqueous phase were precipitated and analyzed by $1.5 \%$ agarose gel electrophoresis. Gel was visualized and photographed under transmitted UV light.

Preparation of cell lysates and immunoblotting

Cells were lysed in $10 \mathrm{mM}$ Tris pH 7.4, $1 \mathrm{mM}$ EDTA, $0.5 \mathrm{mM}$ EGTA, $150 \mathrm{mM} \mathrm{NaCl}, 1 \%$ Triton X-100, $50 \mathrm{mM} \mathrm{NaF}, 10 \mathrm{mM}$ $\mathrm{Na}_{4} \mathrm{P}_{2} \mathrm{O}_{7} \cdot 10 \mathrm{H}_{2} \mathrm{O}, 5 \mu \mathrm{g} / \mathrm{ml}$ aprotinin, $5 \mu \mathrm{g} / \mathrm{ml}$ leupeptin and $1 \mathrm{mM}$ PMSF. Fifty microgram of proteins were electrophoresed in SDSpolyacrylamide gel and transferred onto nitrocellulose membranes (Hybond ${ }^{T M}$ ECL $^{T M}$ ). The membranes were blocked with $5 \%$ skim milk in Tris-buffered saline (TBS) containing $0.1 \%$ Tween-20 (TBS-T) and subsequently incubated with antibodies. After washed with TBS-T, the membranes were incubated with horseradish peroxidase (HRP)-conjugated antibody. Immunoreactive bands were detected with enhanced chemiluminescent reagents (Amersham).

\section{Transfections and luciferase reporter assays}

Plasmids were introduced into AML12 cells with LipofectAMINE. The expressions of p38 and p38AF were identified with immunoblotting. p3TP-Lux plasmid, which contains a luciferase expression unit under the control of PAI-1 promoter, was introduced into AML12 cells together with pRL-SV40. Sixteen hours after transfection, the cells were treated with TGF- $\beta$ $1(10 \mathrm{ng} / \mathrm{ml})$ in culture medium containing $0.25 \%$ FCS. After 16 $\mathrm{h}$, the cells were lysed and the luciferase activity was measured with dual luciferase assay system. The luciferase activity was normalized to pRL-SV40 luciferase activity to account for transfection efficiency and cell viability.

\section{RESULTS}

\section{SB202190 inhibits the TGF- $\beta 1$-induced apoptosis in AML12 hepatocytes}

To test the possible involvement of p38 signaling pathway in TGF- $\beta 1$-induced apoptosis, we first investigated the role of SB202190, a selective inhibitor of $\mathrm{p} 38$, on the TGF- $\beta 1$-induced apoptosis in AML12 cells. Treatment of AML12 cells with TGFb1 for $24 \mathrm{~h}$ resulted in an apoptotic response of cells as detected by the observation of cell morphology and by the appearance of apoptotic nuclei. Pretreatment of cells with SB202190 $(10 \mu \mathrm{M})$ blocked these apoptotic response induced by TGF- $\beta 1$ (Fig 1A). Same results were obtained by DNA fragmentation assay. As shown in Fig $1 \mathrm{~B}$, TGF- $\beta 1$ - induced DNA fragmentation was also completely inhibited by SB202190.

\section{Effect of SB202190 on TGF- $\beta 1$-induced PAI-1 transcription activity}

To determine whether p38 has any effect on TGF- $\beta 1$-induced gene expression, we performed 

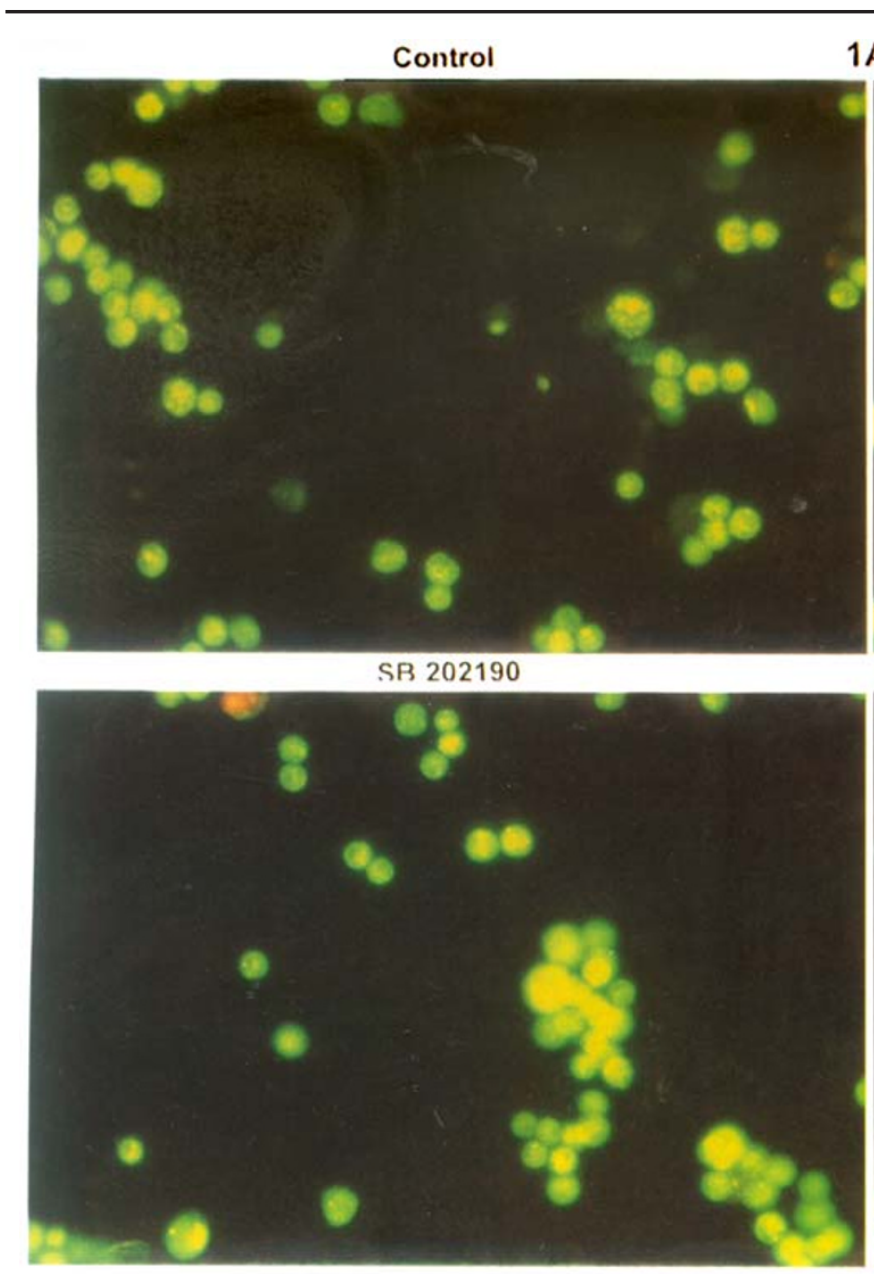

$1 \mathrm{~A}$

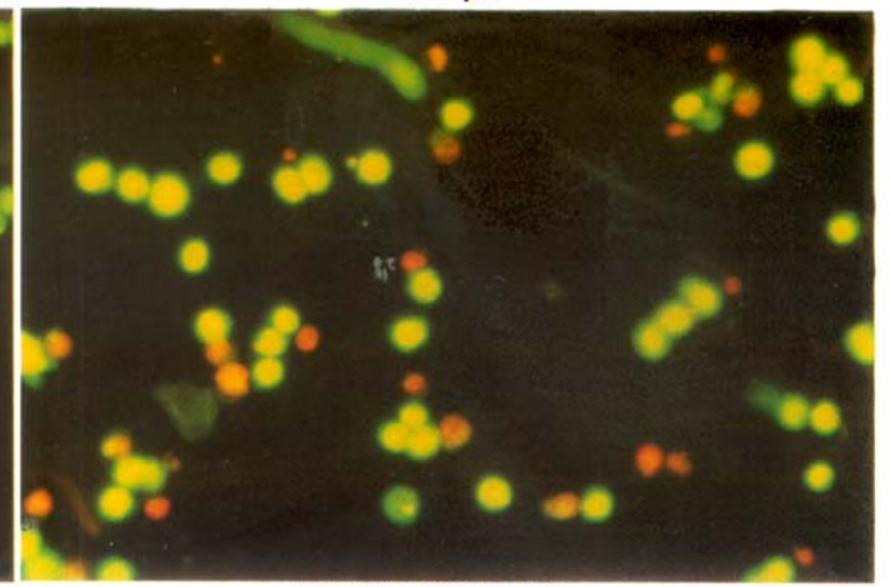

SB 202190 \& TGF-B1

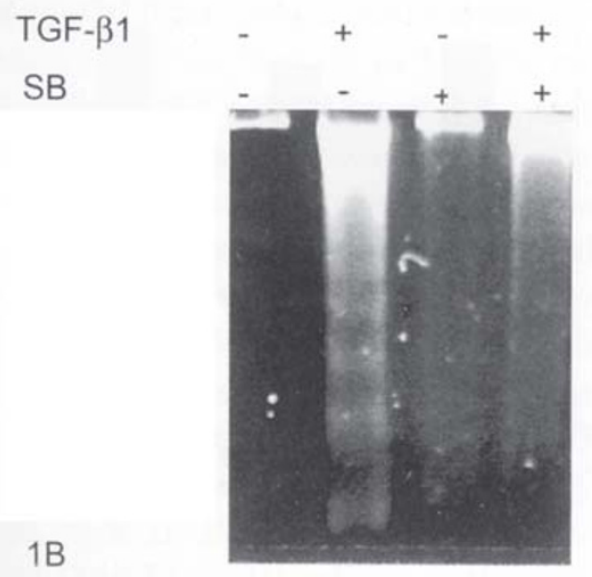

the Luciferase reporter assays. As shown in Fig 2, TGF- $\beta 1$ induced 7.3-fold increase in luciferase activity. Treatment of cells with SB202190 alone did not affect luciferase activity. However, in the presence of $\mathrm{p} 38$, TGF- $\beta 1$-induced luciferase activity in AML12 cells was reduced to 3.0 fold, suggesting a role of p38 in modulating the TGF- $\beta 1$ induced gene expression.

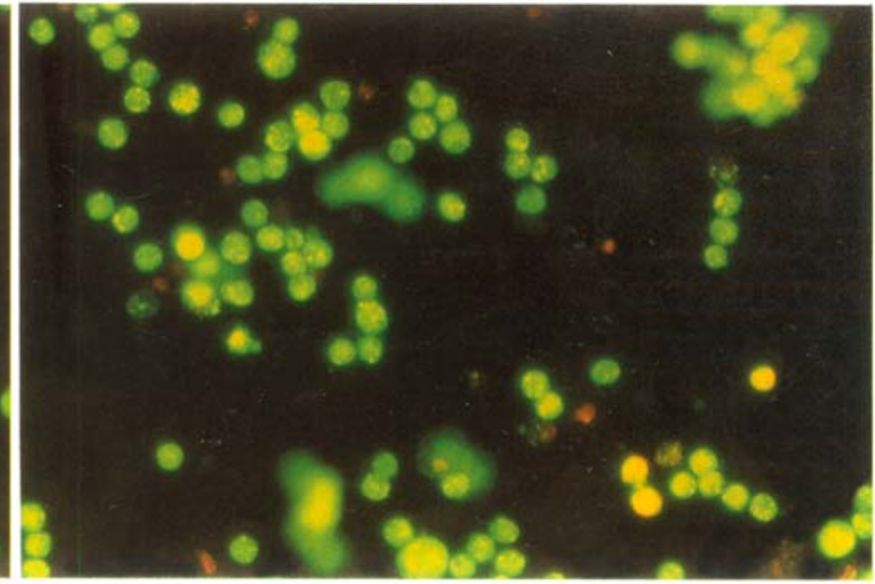

Fig 1. The inhibition of TGF- $\beta$ 1-induced apoptosis by SB202190 (SB) AML12 cells were treated with TGF- $\beta 1(10 \mu \mathrm{g} /$ $\mathrm{ml})$ in the presence or absence of SB 202190 (10 mM). Cells were pre-incubated with SB202190 for 30 min before the addition of TGF- $\beta 1$. Cells were further incubated for $24 \mathrm{~h}$, apoptosis was then determined. (A) Cells were stained by acridine orange and ethidium bromide. Fluorescence was visualized immediately with a fluorescent microscope. (B) DNA fragmentation was detected as described in "Materials and Methods" .

\section{TGF- $\beta 1$ activates p38 MAPK}

To further investigate the involvement of p38 in TGF- $\beta 1$-induced apoptosis, we determined the activation of $\mathrm{p} 38 \mathrm{MAPK}$ in response to TGF- $\beta 1$ treatment by measuring the phosphorylation of p38 with phospho-specific antibody. As shown in Fig 
3A, treatment of cells with TGF- $\beta 1$ induced a rapid activation of $\mathrm{p} 38 \mathrm{MAPK}$, which peaked at 30

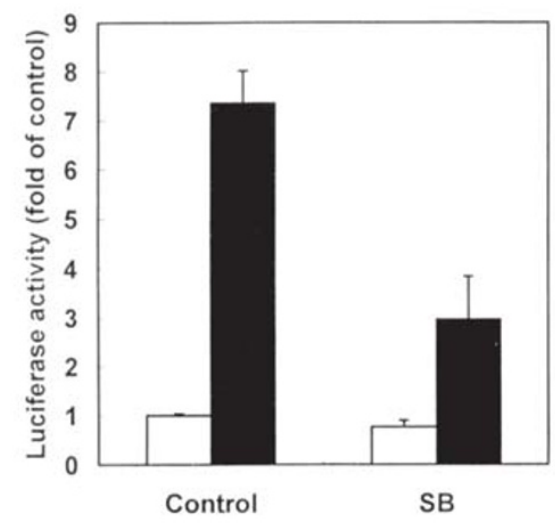

Fig 2. Effect of SB202190 (SB) on TGF- $\beta$ 1-inducible gene expression p3TP-Lux plasmids were introduced into AML12 cells together with pRL-SV40. After transfection, cells were left untreated, treated with TGF-b1 (10 ng/ml), SB $202190(10 \mu \mathrm{M})$, or pre-incubated with SB202190 $(10 \mu \mathrm{M})$ for $30 \mathrm{~min}$ before further incubation with TGF- $\beta 1$ ( $10 \mathrm{ng} / \mathrm{ml})$ for $16 \mathrm{~h}$. Luciferase activities were measured as described in "Materials and Methods" The filled bars represent the treatment of TGF- $\beta 1$.

\section{A}

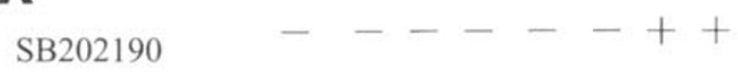

TGF-b1(min) $0 \quad 5153060120030$

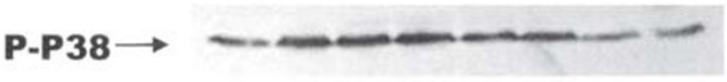

P38

B

TGF-b1(min) $\quad 0 \quad 5 \quad 153060120240$

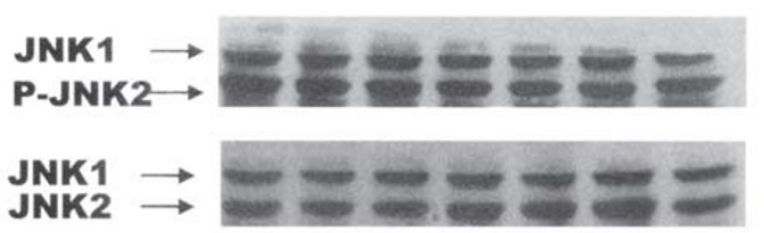

Fig 3. Effects of TGF- $\beta 1$ on the activation of p38 MAPK and JNK AML12 murine hepatocytes were treated with TGF- $\beta 1$ (10 $\mathrm{ng} / \mathrm{ml}$ ) for the indicated time. The activations of p38 MAPK and JNK were determined by immuno-blotting with monoclonal antibodies against phosphorylated p38 and phosphorylated JNK, respectively. (A) TGF- $\beta 1$ activates $\mathrm{p} 38$, which was inhibited by pretreatment of SB $202190(10 \mu \mathrm{M})$ for $30 \mathrm{~min}$. (B) Effects of TGF- $\beta 1$ on JNK activation. min and lasted for at least $2 \mathrm{~h}$, and pretreatment of SB202190 could also inhibit the p38 MAPK activation by TGF- $\beta 1$. No activation of JNK by TGF-b1 was detected during the $4 \mathrm{~h}$ 's treatment (Fig 3B). The results indicate that $\mathrm{p} 38 \mathrm{MAPK}$ but not JNK was activated in TGF- $\beta 1$-induced cell apoptosis.

Dominant negative mutant $p 38$ reduces $T G F$ $\beta 1$ - induced apoptosis in AML12 cells

To investigate the role of $\mathrm{p} 38$ signaling pathway in TGF- $\beta 1$-induced apoptosis, wild type and dominant negative mutant p38 (p38AF) were introduced into AML12 cells. The vector pcDNA3 was also transfected into AML12 cells as a control. After screened with G418, the expression of Flag-tagged

A
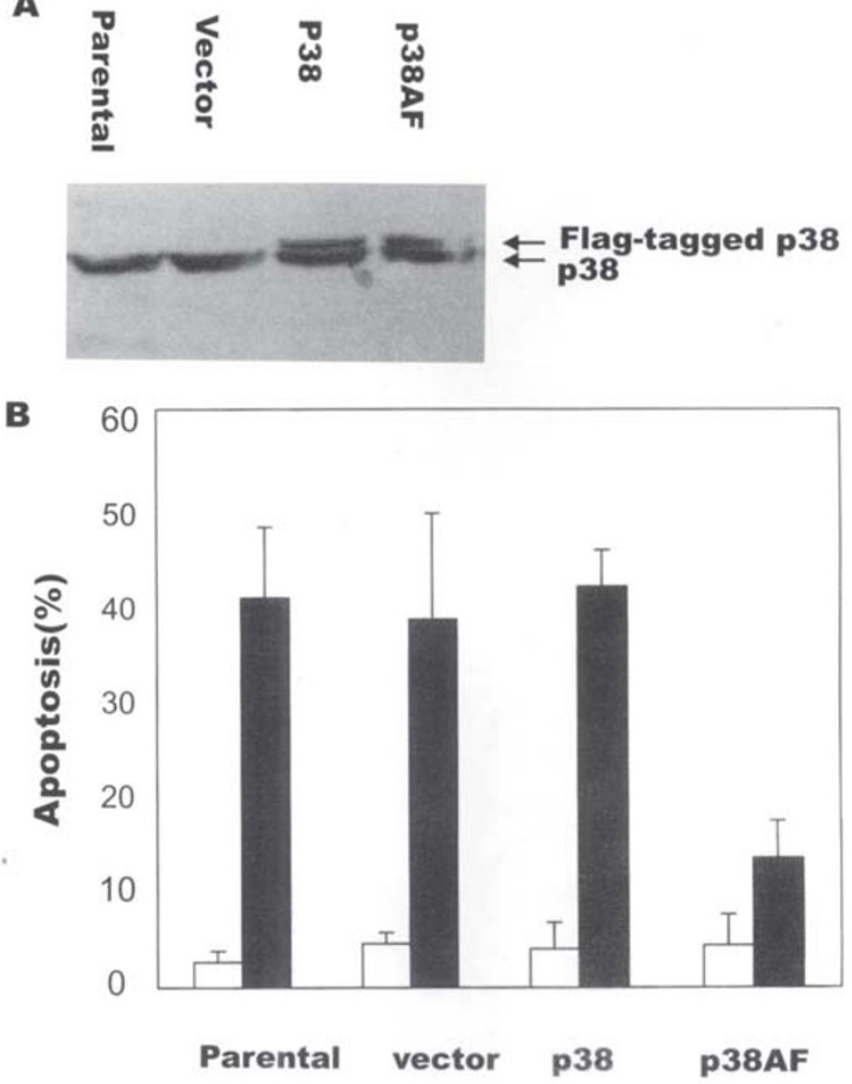

Fig 4. Attenuation of TGF- $\beta$ 1-induced apoptosis by dominant negative mutant of p38 MAPK AML12 cells were transfected with pcDNA3, pcDNA3-Flag-p38, pcDNA3-Flag-p38 (AF). (A) The expression of p38 was detected with anti-p38 antibody. (B) The percentages of apoptotic cells were measured with acridine orange/ethidium staining. The filled bars represent the treatment of TGF- $\beta 1$. Data are the means \pm SD from a representative of 2 experiments performed in triplicates. 
p38 and p38AF were detected with immunoblotting (Fig 4A). The percentage of apoptotic cells was determined with acridine orange/ethidium staining and fluorescent microscopy. Fig 4B demonstrated that dominant negative mutant p38 significantly inhibited TGF- $\beta 1$-induced apoptosis, suggesting that p38 MAPK plays a role in TGF- $\beta 1$-induced apoptosis.

\section{DISSCUSSION}

It was reported that TGF- $\beta$-induced apoptosis is associated with up-regulation of pro-apoptotic molecules such as Bax and p53 and/or with downregulation of anti-apoptotic molecules such as Bcl2 and Bcl-X $\mathrm{X}_{\mathrm{L}}[6],[14],[15]$. TGF-b-induced apoptosis in AML-12 cells can be blocked by the inhibition of protein synthesis[33]. Although the signaling pathways of TGF- $\beta$-mediated many physiological functions have been well described, the signaling mechanisms by which TGF- $\beta$ induce cell apoptosis are not well understood.

TGF- $\beta$ can activate two independent signaling pathways, TAK1- and Smad-mediated pathways, which often interact in the regulation of TGF- $\beta 1$ signaling. It has been reported that Smad3 phosphorylation by JNK facilitates both its activation by the TGF- $\beta$ receptor complex and its nuclear accumulation[34]. It was shown that Smad signaling pathway plays a role in TGF- $\beta$-induced apoptosis. The overexpression of DPC4/Smad4 in MDCK cells is sufficient to induce the activation of gene transcription, cell cycle arrest, and apoptosis[35]. It has also been shown that constitutive expression of Smad3 did not induce apoptosis, but made human normal epithelial cells more sensitive to TGF- $\beta$-induced apoptosis[36].

JNK and p38 MAPK have been shown to mediate apoptosis induced by many stimuli[24-37]. Though it has been shown that TGF- $\beta$ activates JNK and p38 signaling molecules[21-23], their implication in TGF- $\beta$-induced apoptosis is not clear. The fact that TGF- $\beta 1$ induces activation of p38 in AML12 cells suggests that p38 MAPK is probably involved in the TGF- $\beta 1$-induced apoptosis. The results indicate that $\mathrm{p} 38$ signaling pathway was activated in TGF- $\beta 1$-induced apoptosis in AML12 cells. SB202190, an selective inhibitor of p38, completely inhibited TGF- $\beta 1$-induced apoptosis in AML
12 cells. Transfection of a dominant negative mutant of p38 into AML12 cells also significantly reduced the TGF-b1-induced apoptosis. Both specific inhibitor and dominant negative mutant could interfere TGF- $\beta$-induced apoptosis. The data further indicate that $\mathrm{p} 38$ signaling pathway plays a role in TGF- $\beta 1$-induced apoptosis.

\section{ACKNOWLEDGEMENTS}

We are grateful to Dr. Rik Derynck for the TGF$\beta 1$, Dr. Joan MASSGÉ for providing PAI-1 reporter plasmid p3TP-Lux, Dr. Jia Huai HAN for the kind gifts of Plasmids of pcDNA3-Flag-p38, pcDNA3Flag-p38(AF), He Hua CHEN for helpful discussion. This work was supported by grants from the Chinese Academy of Sciences (No. KJ951-B1608), the National Natural Sciences Foundation of China (No. 39625007 and 39870396).

\section{REFERENCES}

[1] Jacobson MD, Weil M, Raff MC. Programmed cell death in animal development. Cell 1997; 88(3):347-54.

[2] Schulte-Hermann R, Bursch W, Low-Baselli A, Wagner A, Grasl-Kraupp B. Apoptosis in the liver and its role in hepatocarcinogenesis. Cell Biol Toxicol 1997; 13(4-5): 339-48.

[3] Zhou BH, Chen JS, Chai MQ et al. Activation of phospholipase D activity in transforming growth factor-b-induced cell growth inhibition. Cell Res 2000; 10(2):13949.

[4] Schez A, Alvarez AM, Benito M, Fabregat I. Apoptosis induced by transforming growth factor-b in fetal hepatocyte primary cultures: involvement of reactive oxygen intermediates. J Biol Chem 1996; 271(13):741622.

[5] Chen RH, Chang TY. Involvement of caspase family proteases in transforming growth factor-b-induced apoptosis. Cell Growth Differ 1997; 8(7):821-7.

[6] Teramoto T, Kiss A, Thorgeirsson SS. Induction of p53 and Bax during TGF-b1 initiated apoptosis in rat liver epithelial cells. Biochem Biophys Res Commun 1998; 251(1):56-60.

[7] Arsura M, FitzGerald MJ, Fausto N, Sonenshein GE. Nuclear factor-kB/Rel blocks transforming growth factor b1-induced apoptosis of murine hepatocyte cell lines. Cell Growth Differ 1997; 8(10):1049-59.

[8] Fukuda K, Kojiro M, Chiu JF. Induction of apoptosis by transforming growth factor-b1 in the rat hepatoma cell line McA-RH7777: a possible association with tissue transglutaminase expression. Hepatology 1993; 18(4): 945-53.

[9] Choi KS, Lim IK, Brady JN, Kim SJ. ICE-like protease (caspase) is involved in transforming growth factor $\beta 1$ mediated apoptosis in $\mathrm{FaO}$ rat hepatoma cell line. Hepatology 1998; 27(2):415-21. 
[10] Ohba M, Shibanuma M, Kuroki M, Nose K. Production of hydrogen peroxide by transforming growth factor-b 1 and its involvement in induction of egr-1 in mouse osteoblastic cells. J Cell Biol 1994; 126(4):1079-88.

[11] Thannickal VJ, Hassoun PM, White AC, Fanburg BL. Enhanced rate of $\mathrm{H} 2 \mathrm{O} 2$ release from bovine pulmonary artery endothelial cells induced by TGF- $\beta 1$. Am J Physiol 1993; 265(6 Pt 1):L622-6.

[12] Lafon CL, Mathieu C, Guerrin M, Pierre O, Vidal S, Valette A. Transforming growth factor b1-induced apoptosis in human ovarian carcinoma cells: protection by the antioxidant $\mathrm{N}$-acetylcysteine and bcl-2. Cell Growth Differ 1996; 7(8):1095-104.

[13] Brown TL, Patil S. Basnett RK, Howe PH. Caspase inhibitor BD-fmk distinguishes transforming growth factor $\beta$-induced apoptosis from growth inhibition. Cell Growth Differ 1998; 9(10):869-75.

[14] Saltzman A, Munro R, Searfoss G, Franks C, Jaye M, Ivashchenko Y. Transforming growth factor- $\beta$-mediated apoptosis in the Ramos B-lymphoma cell line is accompanied by caspase activation and Bcl-XL downregulation. Exp Cell Res 1998; 242(1):244-54.

[15] Motyl T, Grzelkowska K, Zimowska W, Skierski J, Wareski P, Ploszaj T, Trzeciak L. Expression of bcl-2 and bax in TGF- $\beta$ 1-induced apoptosis of L1210 leukemic cells. Eur J Cell Biol 1998; 75(4):367-74.

[16] Heldin CH, Miyazono K, ten Dijke P. TGF- $\beta$ signalling from cell membrane to nucleus through SMAD proteins. Nature 1997; 390(4):465-71.

[17] Derynck R, Zhang Y, Feng XH. Smads: transcriptional activators of TGF- $\beta$ responses. Cell 1998; 95(6):73740.

[18] Kretzschmar M, Massague J. SMADs: mediators and regulators of TGF- $\beta$ signaling. Curr Opin Genet Dev 1998; 8(1):103-11.

[19] Whitman M. Smads and early developmental signaling by the TGF-b superfamily. Genes Dev 1998; 12(16): 2445-62.

[20] Yamaguchi K, Shirakabe K, Shibuya H, Irie K, Oishi I, Ueno N, Taniguchi T, Nishida E, Matsumoto K. Identification of a member of the MAPKKK family as a potential mediator of TGF- $\beta$ signal transduction. Science 1995; 270(5244):2008-11.

[21] Moriguchi T, Kuroyanagi N, Yamaguchi K, Gotoh Y, Irie K, Kano T, Shirakabe K, Muro Y, Shibuya H, Matsumoto K, Nishida E, Hagiwara M. A novel kinase cascade mediated by mitogen-activated protein kinase kinase 6 and MKK3. J Biol Chem 1996; 271(23):13675-9.

[22] Wang W, Zhou G, Hu MCT, Yao Z, Tan TH. Activation of the hematopoietic progenitor kinase-1 (HPK1)dependent, stress-activated c-Jun $\mathrm{N}$-terminal kinase (JNK) pathway by transforming growth factor $\beta$ (TGFb)-activated kinase (TAK1), a kinase mediator of TGF $\beta$ signal transduction. J Biol Chem 1997; 272(36): 22771-5.

[23] Hanafusa H, Ninomiy-Tsuji J, Masuyama N, Nishita M, Fujisawa J, Shibuya H, Matsumoto K, Nishida E. In- volvement of the p38 mitogen-activated protein kinase pathway in transforming growth factor- $\beta$-induced gene expression. J Biol Chem 1999; 274(38):27161-7.

[24] Ichijo H. From receptors to stress-activated MAP kinases. Oncogene 1999; 18(45):6087-93.

[25] Graves JD, Draves KE, Craxton A, Saklatvala J, Krebs EG, Clark EA. Involvement of stress-activated protein kinase and p38 mitogen-activated protein kinase in mIgM-induced apoptosis of human B lymphocytes. Proc Natl Acad Sci USA 1996; 93(24):13814-8.

[26] Kawasaki H, Morooka T, Shimohama S, Kimura J, Hirano T, Gotoh Y, Nishida E. Activation and involvement of p38 mitogen-activated protein kinase in glutamate-induced apoptosis in rat cerebellar granule cells. J Biol Chem 1997; 272(30):18518-21.

[27] Kummer JL, Rao PK, Heidenreich KA. Apoptosis induced by withdrawal of trophic factors is mediated by p38 mitogen-activated protein kinase. J Biol Chem 1997; 272(33):20490-4.

[28] Huot J, Houle F, Rousseau S, Deschesnes RG, Shah GM, Landry J. SAPK2/p38-dependent F-actin reorganization regulates early membrane blebbing during stressinduced apoptosis. J Cell Biol 1998; 143(5):1361-73.

[29] Hocevar BA, Brown TL, Howe PH. TGF- $\beta$ induces fibronectin synthesis through a c-Jun N-terminal kinase-dependent, Smad4-independent pathway. EMBO J 1999; 18(5):1345-56.

[30] Atfi A, Djelloul S, Chastre E, Davis R, Gespach C. Evidence for a role of Rho-like GTPases and stressactivated protein kinase/c-Jun $\mathrm{N}$-terminal kinase (SAPK/JNK) in transforming growth factor $\beta$-mediated signaling. J Biol Chem 1997; 272(3):1429-32.

[31] Spector DL, Goldman RD, Leinwand LA. Cell: a laboratory mannual. culture and biochemical analysis of cells. 1998; Vol 1. Cold spring harbor laboratory press.

[32] Lindenboim L. Diamond R. Rothenberg E. Stein R. Apoptosis induced by serum deprivation of PC12 cells is not preceded by growth arrest and can occur at each phase of the cell cycle. Cancer Res 1995; 55(6):1242-7.

[33] Liao JH, Zhou BH, Chai MQ, Song JG. Cycloheximide blocks TGF- $\beta 1$-induced apoptosis in murine heptocytes. Acta Pharmacologica Sinica 2000; 22(2): 176-82.

[34] Engel ME, McDonnell MA, Law BK, Moses HL. Interdependent SMAD and JNK signaling in transforming growth factor- $\beta$-mediated transcription. J Biol Chem 1999; 274(52):37413-20.

[35] Atfi A, Buisine M, Mazars A, Gespach C. Induction of apoptosis by DPC4, a transcriptional factor regulated by transforming growth factor- $\beta$ through stress-activated protein kinase/c-Jun N-terminal kinase (SAPK/ JNK) signaling pathway. J Biol Chem 1997; 272(40): 24731-4.

[36] Yanagisawa K, Osada H, Masuda A, Kondo M, Saito T. Yatabe Y, Takagi K, Takahashi T, Takahashi T. Induction of apoptosis by Smad3 and down-regulation of Smad3 expression in response to TGF- $\beta$ in human normal lung epithelial cells. Oncogene 1998; 17(13):1743-7. 